\title{
HADIS QUDSI DALAM PERSPEKTIF PSIKOLOGI TRANSPERSONAL
}

\author{
Abdul Fatah Idris \\ Universitas Islam Negeri Walisongo Semarang \\ e-mail: fatah_idris@walisongo.ac.id
}

\begin{abstract}
Hadith Qudsi is a hadith which its meaning and text come from the Prophet Muhammad. In fact, the Quran and the Hadith also come from the revelation internally (from the deep heart of the Prophet) and nonverbal (not words form). To understand the meaning of hadith qudsi, the author uses the revelation theory through transpersonal psychology. The study found explanations that there are three categories of prophet speech: the Quran, hadith Nabawi, and hadith qudsi. These all come from the inspiration of Ilahi (the revelation of God), not in the form of words or language. Then, the prophet created human language (texts) and applied them in his daily life.
\end{abstract}

Abstrak: Hadis qudsi adalah hadis yang makna kandungan maupun lafadhnya berasal dari Nabi Muhammad. Sebenarnya, al-Qur'an dan hadis juga berasal dari wahyu yang bersifat internal (dari lubuk hati terdalam nabi) dan nonverbal (tidak berbentuk perkataan). Untuk memahami arti hadis qudsi, penulis menggunakan teori pewahyuan dengan melalui pendekatan psikologi transpersonal. Artikel ini menemukan bahwa ada tiga kategori perkataan yang melalui Nabi Muhammad yaitu berbentuk al-Qur'an, hadis nabawi, dan hadis qudsi. Semuanya berasal dari inspirasi Ilahi (wahyu Tuhan), yang bukan berbentuk perkataan ataupun bahasa. Lalu, Nabi menciptakannya dalam untaian bahasa manusia (teks), dan menampakkannya dalam perilaku kesehariannya.

Keywords: teori pewahyuan; revelation; hadis qudsi; hadis nabawi; psikologi transpersonal

\section{A. Pendahuluan}

Ada dua ayat ${ }^{1}$ al-Qur'an yang menegaskan bahwa Nabi Muhammad merupakan utusan Tuhan yang perkataan dan tindakannya selalu berdasarkan "wahyu". Kendati arti literal kedua ayat ini sangat jelas, namun dalam rentang sejarah yang sangat panjang tak ada habisnya para sarjana klasik maupun kontemporer berbincang tentang "konsep wahyu" yang menjadi penanda bagi kenabian Nabi Muhammad.

1"Dan tiadalah yang diucapkannya itu menurut kemauan hawa nafsunya. Ucapannya itu tiada lain hanyalah wahyuyang diwahyukan." (QS. al-Najm [53]: 3-4). 
Dari wahyu yang diterima Nabi Muhammad, terciptalah al-Qur'an dan hadis qudsi maupun hadis nabawi. Karenanya, pemahaman tentang konsep wahyu memiliki hubungan yang erat dengan definisi kedua teks peninggalan Nabi itu. Sederhananya, hubungan antara wahyu al-Qur'an dan hadis qudsi dapat dirangkum dalam sebuah pertanyaan; Apakah al-Qur'an dan hadis qudsi sebagai perkataan Nabi Muhammad, atau perkataan (kalam) Tuhan? Atau dalam bahasa yang lebih tegas; Apakah keduanya sebagai karya Nabi Muhammad, atau karya Tuhan? Jika keduanya sebagai karya Tuhan kenapa menggunakan bahasa Arab yang menjadi bahasa keseharian Nabi Muhammad? Dan sejumlah pertanyaan lainnya, yang kesemuaannya membutuhkan jawaban dari kata kunci "konsep wahyu”.

Sejak masa kodifikasi ilmu-ilmu keislaman,1 termasuk di dalamnya kodifikasi hadis, para sarjana banyak berspekulasi menggambarkan proses penerimaan wahyu dari Tuhan kepada Nabi Muhammad. Salah satu konsekuensi konsep wahyu hasil interpretasi sarjana keislaman abad ini adalah lahirnya istilah "hadis qudsi", yaitu hadis yang dalam definisi mereka; maknanya berasal dari Tuhan dan lafalnya hasil kreasi Nabi Muhammad.

Rumusan definisi demikian bertujuan untuk membedakannya dengan hadis nabawi dan al-Quran. Zakaria Ouzon dalam karyanya Jināyah al-Bukhārī, menyatakan bahwa hadis qudsi adalah istilah yang dibuat oleh sarjana ahli fikih masa lalu yang kini terbukti kebohongannya. Bagi Ouzon, hadis qudsi tidak bisa diyakini karena ada dua alasan utama, yaitu: Pertama istilah tersebut tidak terdapat di dalam al-Qur'an dan tidak pernah digunakan Nabi Muhammad, dan Kedua redaksi hadis qudsi mengandung kosakata yang rendah yang tidak pantas disandarkan kepada Tuhan. ${ }^{2}$

Sedangkan hadis qudsi yang dalam kitab Șậịh al-Bukhārī banyak diriwayatkan oleh Abū Hurairah, sehingga seakan-akan istilah ini sudah diguna-

1Yaitu tersusunnya kitab kitab pada akhir abad II dan III misalnya kitab kitab tafsir dan hadis yang dikarang oleh Sufyan bin Sa'd bin Mashrūq al-Thaury (w. 161 H.), dan kitab hadis yang disusun dengan metode konten ala fikih seperti kitab al-Muwatța' oleh Malik bin Anas bin Malik bin Abi 'Āmir al-Thaury (w. 179 H.). Kemudian disusuli dengan kitab kitab lain seperti kitab Imam al-Bukhari (194-256 H), Imam Muslim (204-261 H), al-Sunan Abu Dawud, (202-275 H), Musnad Ahmad bi Hanbal dan Sunan al-Nasāi (wafat 303 H), lihat: Subhi al-Șālih, 'Ulūm al-Hadīth wa Muștalahuhu, (Bairut: Dār al-Ilm li'l-Malayin, 1978), 91, 117, 122. Lihat pula: Abu Sahl Muhammad bin 'Abdurrahman, al-Mawsū'ah, jilid 2 (Mesir: al-Nabla, t.th.), 394.

2Zakaria Ouzon, Jināyah al-Bukhārī; Inqādh al-Dīn min Imām al-Muḥaddithīn, (Beirut: Riad ElRayyes Books, 2004), 49-55. 
kan oleh sebagian sahabat nabi, menurut Ouzon tidak benar, karena selain sosok Abū Hurairah tidak bisa dipercaya, ${ }^{3}$ juga al-Bukhārī sebagai penulis kitab Șahịh al-Bukhārī telah melakukan banyak dusta di dalam karyanya dengan membuat hadis-hadis palsu yang memiliki kandungan melecehkan Nabi Muhammad. ${ }^{4}$

Tulisan ini bukan sebagai tanggapan atas wacana Zakaria Ouzon yang tidak mengakui hadis qudsi, namun dengan mengidentifikasi hadis qudsi yang dihasilkan dari pembacaan terhadap teori pewahyuan, maka wacana Ouzon secara tidak langsung akan menemukan tanggapannya.

Pembahasan hadis qudsi dalam tulisan ini menggunakan teori pewahyuan melalui Nabi Muhammad dengan pendekatan psikologi transpersonal. ${ }^{5}$ Konsepsi penerimaan wahyu oleh para sarjana klasik yang melahirkan konsep al-qur'an sebagai wahyu yang datangnya dari Tuhan dan hadis sebagai sesuatu yang datangnya dari Nabi kiranya masih menyisakan problem. Oleh karena itu diperlukan sebuah penjelasan yang komperhensip tentang konsep hadis qudsi agar dapat menemukan sebuah pendefinisian yang kredibel secara ilmiah.

\section{B. Konsep Wahyu dalam al-Qur'an}

Wahyu secara etimologi memiliki beberapa arti, yaitu:6 isyarat, tulisan, surat, ilham, perkataan yang samar, dan semua informasi yang diberikan kepada orang lain. Menurut Abū Ishạāq sebagaimana dikutip Ibnu Mandhūr, makna asal kata

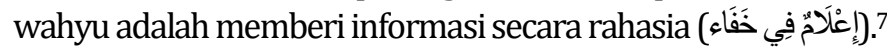

${ }^{3}$ Menurut Ouzon, Abū Hurairah tidak bisa dipercaya karena banyak faktor, antara lain: Abū Hurairah mengalami hidup bersama Nabi Muhammad, hanya satu tahun lebih sembilan bulan, namun hadis yang diriwayatkannya sangat banyak sekali hingga tidak sebanding dengan jumlah hari, bulan dan tahun, itu pun apabila seandainya setiap hari Abū Hurairah bertemu Rasulullah. Oleh karenanya, istri Nabi yang selalu menemani Nabi hingga akhir hayatnya, 'Á'ishah, banyak mengingkari hadis-hadis yang disampaikan Abū Hurairah. Selain itu, pada masa tampuk kekuasaan Islam dipegang Umar bin Khațāāb, Abū Hurairah telah melakukan korupsi uang bait al-māl ketika dirinya menjabat sebagai pemimpin daerah Bahrain. Hal ini menjadikan Umar marah dan mengatakan Abū Hurairah sebagai musuh Islam, musuh Allah, dan musuh kitab-Nya. Sebab tindakannya yang amoral dan kelakuannya yang sering membuat hadis-hadis palsu, Abū Hurairah dipukul oleh 'Umar hingga berdarah, dan Abū Hurairah dilarang menyampaikan hadis dan diusir dari tanah Bahrain. Selengkapnya, lihat Ouzon, Jināyah al-Bukhārī, 20-21.

${ }^{4}$ Ouzon, Jināyah al-Bukhārī, 25.

5Psikologi transpersonal adalah, sebagai "psikologi spiritual" transpersonal didefinisikan sebagai "pengalaman di mana rasa identitas atau diri melampaui (trans) individu atau pribadi untuk mencakup aspek yang lebih luas dari manusia, hidup, jiwa atau kosmos". Lihat: Walsh, R. \& Vaughan, F. "On transpersonal definitions". Journal of Transpersonal Psychology, 25 No. 2 (1993): 125-182.

6Ibnu Mandhūr al-Anshārī, Lisān al-'Arab, Vol.XV (Beirut: Dār Șādir, 1414 H.), 379.

${ }^{7}$ al-Anshārī, Lisānu al-'Arab, 381. 
Sedangkan arti kata wahyu dalam terminologi 'ulūm al-Qur'ān memiliki dua makna. Keduanya tidak jauh berbeda dengan makna wahyu secara kebahasaan. Pertama, firman Allah yang diturunkan kepada nabi-Nya. Kedua, pemberian informasi dari Allah kepada nabi-Nya tentang hal-hal yang dikehendaki Allah, baik berupa hukum syariat atau risalah kenabian yang bersifat rahasia dan di luar kebiasaan sistem komunikasi manusia. ${ }^{8}$

Kedua makna ini sebenarnya sama, hanya saja makna yang pertama mem-

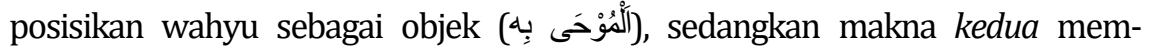
posisikannya sebagai predikat atau proses pewahyuan yang diambil dari mashdar al-ịhā' (الإيحاء). Letak kesamaan kedua makna ini yaitu wahyu sebagai media komunikasi tidak bersifat timbal balik, melainkan berjalan hanya dari satu pihak saja (dari pemberi ke penerima).

Dalam al-Qur'an kata wahyu dengan beragam bentuknya disebut sebanyak 78 kali. ${ }^{9}$ Para penafsir (mufassir) memberikan arti beraneka ragam. Ada yang diartikan dengan ilham, isyarat, bisikan, dan perintah.

Pertama, kata wahyu diartikan dengan ilham seperti ayat:

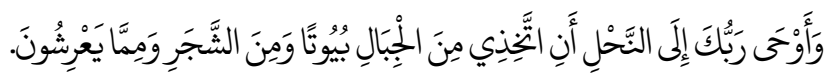

"Dan Tuhanmu memberikan ilham (wa auhā) kepada lebah: buatlah sarang-sarang di bukit-bukit, di pohon-pohon kayu, dan di tempat-tempat yang dibikin manusia." (QS. al-Nahl [16]: 68)

Para mufassir besar seperti al-Ṭabarī, al-Qurțubī, al-Zamakhsyarī, dan Ibn Kathīr, mengartikan kata wahyu dalam ayat ini dengan ilham, yaitu Allah memberikan ilham kepada binatang lebah berupa perintah untuk membuat sarang di tempat-tempat yang aman seperti di gunung, pohon kayu besar, dan di tempat-tempat yang dibuat oleh manusia. ${ }^{10} \mathrm{Al}-\mathrm{Qurțub} \overline{\mathbf{I}}^{11}$ memberikan pen-

\footnotetext{
${ }^{8}$ Abdul 'Aẓīm al-Zarqānī, Manāhil al-Irfān, Vol. I (Kairo: Dār al-Ḥadīth, 2001), 56.

${ }^{9}$ Muhammad Fu’ād ‘Abdul Bāqī, Al-Mu'jam al-Mufahras li Alfāz al-Qur'ān al-Karīm (Kairo: Dār al-ㅂadìts, 1364 H.), 746-747.

${ }^{10}$ Lihat: Muhammad Ibnu Jarīr al-Tabarī,Jāmi' al-Bayān fi Ta wìl al-Qur'ān (ttp., Mu assasah arRisālah, 2000,),voi. XVII, 247-248. Abū 'Ábdillah al-Qurțubī, al-Jāmi' li Ahkkām al-Qur'ān (Kairo: Dār alKutub al-Mishriyah, 1964), vol. X, 133-134. Abū al-Qāsim al-Zamakhsyarī, al-Kashshäf 'an Haqā īq Ghawāmiḍ al-Tanzīl (Beirut: Dār al-Kitāb al-'Arabī, 1407 H.), vol. II, 618. Abū al-Fidā’ Ibnu Kathīr, Tafsìr al-Qur'ān al-Azìm (Beirut: Dār al-Kutub al-'Ilmiyah, 1419 H.), vol. IV, 499.
}

${ }^{11}$ al-Qurțubī, al-Jāmi' li Aḥkām al-Qur'ān,133. 
jelasan bahwa Allah menciptakan pengetahuan di dalam hati binatang lebah tanpa didahului oleh sebab yang kasat mata.

Kedua, kata wahyu diartikan dengan isyarat seperti:

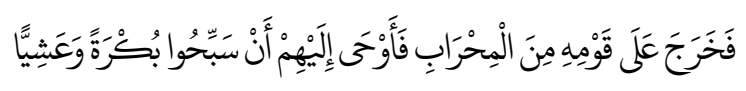

"Maka ia keluar dari mihrab menuju kaumnya, lalu ia memberi isyarat (fa auhāa) kepada mereka: hendaklah kamu bertasbih di waktu pagi dan petang." (QS. Maryam [19]: 11)

Para mufassir klasik mengartikan kata wahyu dalam ayat ini dengan isyarat, yakni Nabi Zakariya memberikan isyarat kepada kaumnya untuk bertasbih di waktu pagi dan petang. Hanya saja para sarjana ini berbeda pendapat tentang "alat" yang digunakan sebagai isyaratnya. Dalam magnum opus-nya, al-Ṭabari menyampaikan tiga pendapat: Pertama, alat isyarat berupa tangan. Kedua, berupa tulisan. Ketiga, berupa perintah. ${ }^{12}$

Ketiga, kata wahyu diartikan sebagai bisikan seperti dalam QS. al-An’ām [6]: 121:

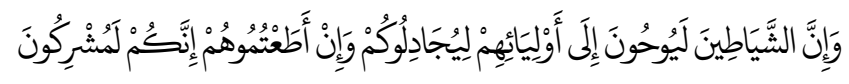

"Sesungguhnya syaitan itu membisikkan (layūhūna) kepada kawankawannya agar mereka membantah kamu, dan jika kamu menuruti mereka, sesungguhnya kamu tentulah menjadi orang-orang yang musyrik."

Para sarjana klasik menafsirkan kata wahyu dalam ayat ini dengan bisikan, yakni setan membisiki manusia dengan berbagai bujukan. ${ }^{13}$

Keempat, kata wahyu diartikan sebagai perintah seperti tersebut dalam QS. al-Anfāl [8]: 12:

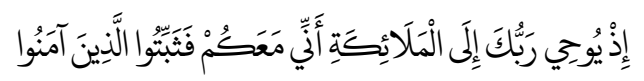

"Ketika Tuhanmu memerintahkan kepada malaikat: sesungguhnya aku bersama kamu, maka teguhkan (pendirian) orang-orang yang telah beriman."

12Lihat: al-Ṭabarī, Jāmi' al-Bayān, 153-155. Lihat juga al-Qurțubī, al-Jāmi' li Aḥām, 85; alZamakhsyarī, al-Kashshāf, 3; Ibnu Kathīr, Tafsīr al-Qur'ān al-'Aẓīm,191.

13al-Ṭabarī, Jāmi' al-Bayān, 77-78. 
Para sarjana menafsirkan kata wahyu dalam ayat ini dengan perintah, yakni perintah Allah kepada malaikat untuk menolong orang-orang yang beriman. ${ }^{14}$

Keanekaragaman makna wahyu dalam al-Qur'an sebagaimana yang dijelaskan para penafsir di atas memperlihatkan bahwa secara semantik kata wahyu memiliki makna yang begitu luas, namun keluasan makna ini tidak lepas dari makna asalnya, yaitu pemberian informasi secara samar.

\section{Teori Pewahyuan dalam Pandangan Ulama}

Kata wahyu merupakan istilah yang sudah lama dikenal bangsa Arab pra Islam (jāhiliyah) yang kemudian diadopsi al-Quran. Para penyair Arab pra Islam banyak yang menggunakan kata ini dalam syairnya, sebagaimana syair gubahan al-Qamah:

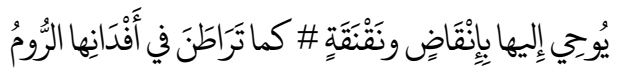

"Burung onta jantan berbicara (yūhî) kepadanya dengan suara inqādl (suara gemeretak, bahasa yang digunakan burung onta jantan) dan naqnaqah (suara gemeretak, bahasa yang digunakan burung onta betina) sebagaimana orang Yunani berbicara satu sama lain dengan bahasa yang tak diketahui (tarāthana) di istananya (Rum)."15

Kata wahyu dalam syair ini digunakan untuk menunjukkan arti komunikasi yang "tidak jelas" bagi pihak yang tidak terlibat, yakni komunikasi tersebut hanya dipahami oleh dua pihak yang bercakap-cakap.

Nașr Ḥāmid Abū Zaid dalam karya monumentalnya, Mafhūm al-Naș, secara panjang lebar menjelaskan bahwa komunikasi dengan cara rahasia seperti ini sudah sangat populer di kalangan masyarakat Arab pra Islam. Komunikasi ini akrab dilakukan para penyair dan ahli peramal (كاهن) dengan para mahluk jin. ${ }^{16}$

Lebih jauh Abū Zaid menegaskan:

14al-Ṭabarī, Jāmi' al-Bayān, h. 428.

15al-Mufaḍal bin Muḥammad al-Ḍabbī, al-Mufaḍḍaliyāt (Kairo: Dār al-Ma'ārif,t.th.), h. 400.

16Lihat: Nașr Hāmid Abū Zaid, Mafhūm al-Naș; Dirāsah fi Ulūm al-Qur'ān, (Mesir: al-Hai'ah alMishriyah al-'Āmmah li al-Kitāb, 1990), 38-45. 


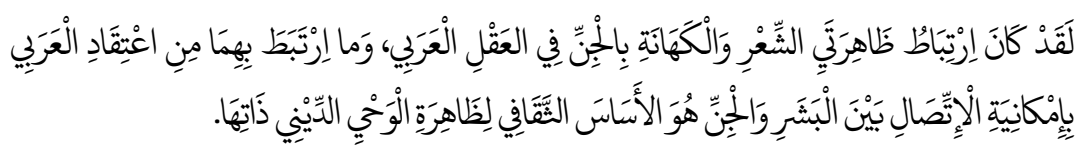

"Hubungan puisi dan perdukunan dengan jin dalam nalar Arab pra Islam, serta keyakinan kemungkinan manusia dapat berkomunikasi dengan jin yang sudah mengakar urat di dalam masyarakat Arab pra Islam merupakan landasan kultural bagi lahirnya wahyu keagamaan."17

Jadi, bagi Abū Zaid konsep wahyu dalam Islam lahir dari budaya masyarakat yang meyakini manusia dapat bercakap-cakap dengan alam gaib. Kesamaan konsep Islam dengan budaya Arab tidak hanya dalam persoalan wahyu, melainkan hampir dalam semua ajaran-ajarannya. Jawwād Alī dalam penelitiannya yang ditulis dalam buku berjudul al-Mufașșal fi Tārīkh al-'Arab qabla al-Islām membuktikan bahwa semua ajaran Islam mulai dari konsep ketuhanan, ritual, hingga hukum-hukumnya tidak lebih dari potret kebudayaan dan keagamaan masyarakat Arab pra Islam. ${ }^{18}$

Konsep wahyu yang diwacanakan para sarjana konservatif sebagaimana yang tertuang dalam buku-buku 'ulūm al-Qur'ān menyatakan bahwa Nabi Muhammad menerima wahyu dari Tuhan dengan dua metode penyampaian; Pertama, wahyu disampaikan Allah tanpa melalui perantara (pihak ketiga), baik berupa ilham, mimpi, atau berbicara langsung. Kedua, wahyu Allah disampaikan melalui perantara malaikat Jibril. Allah terlebih dahulu memberikan wahyu-Nya kepada malaikat Jibril, lalu malaikat Jibril menyampaikan kepada Nabi Muhammad. ${ }^{19}$

Wacana konsep pewahyuan demikian merupakan "ijtihad primitif" yang terpengaruh oleh kebudayaan masyarakat Arab pra Islam yang meyakini bahwa manusia bisa berkomunikasi dengan jin. Kesamaan ajaran Islam dengan budaya Arab pra Islam, termasuk di dalamnya tentang konsep pewahyuan, harus dibaca secara kontekstual dan rasional. Wujud malaikat Jibril yang dipahami sebagai "kurir" firman Tuhan dalam wacana klasik tidak harus diikuti lantaran konsep tersebut -sebagaimana disampaikan oleh Fazlur Rahman- diformulasikan oleh

17Zaid, Mafhūm al-Naș, 38.

18Baca: Jawwād Alī, al-Mufașșal fi Tārīkh al-'Arab qabla al-Islām (Universitas Baghdad, t.th.). XXVII, 160

${ }^{19}$ Fakhruddīn al-Rāzi, Tafsīr Mafātīh al-Ghayb (Beirut: Dār al-Kutub al-'Ilmiyah, 2000), vol. 
sarjana klasik yang terpengaruh oleh doktrin-doktrin Kristen pada abad kedua dan ketiga hijriyah demi menegaskan outentisitas wahyu sebagai kalam Tuhan. Namun sayangnya konsep yang ditawarkan ortodoksi Islam ini gagal lantaran tidak memiliki piranti intelektual yang memadai. ${ }^{20}$

Menurut Fazlur Rahman, prosesi penerimaan wahyu bukan bersifat eksternal sebagaimana dalam wacana ortodoksi Islam, yakni malaikat Jibril mendatangi Nabi lalu menyampaikan pesan "langit"nya. Melainkan bersifat internal (psikologis), yakni wahyu datang dari dalam diri Nabi sendiri. ${ }^{21}$ Wacana ini berdasarkan pada argumentasi yang disampaikan oleh al-Qur'an:

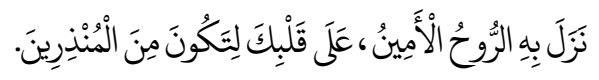

(dia itu dibawa turun oleh al-Rūh al-Amīn (Jibril), ke dalam hatimu (Muhammad) agar kamu menjadi salah seorang di antara orang-orang yang memberi peringatan) (QS. al-Shu'ārā [26]: 193-194).

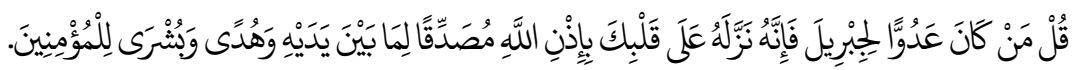

(Katakanlah: Barangsiapa yang menjadi musuh Jibril, maka Jibril itu telah menurunkannya (al-Qur'an) ke dalam hatimu dengan seizin Allah membenarkan apa (kitab-kitab) yang sebelumnya dan menjadi petunjuk serta berita gembira bagi orang-orang yang beriman (Dua ayat ini menegaskan bahwa ar-rūh al-amīn (الروح الأمين) masuk ke dalam hati Nabi Muhammad (QS. al-Baqarah [2]: 97)

Pengalaman spiritual ini menurut Fazlur Rahman terjadi dalam keadaan Nabi Muhammad setengah sadar atau kwasi mimpi, dengan bukti ketika prosesi wahyu selesai Nabi mengatakan "kemudian aku terjaga". Tentu, wacana demikian secara tidak langsung menolak anggapan-anggapan sebagian sarjana Barat yang menuduh Nabi Muhammad mengidap epilepsi, ${ }^{22}$ karena andai Nabi terkena penyakit ayan maka kondisi setengah sadar juga akan dialami sejak

20Fazlur Rahman, Islam (Chicago-London: University of Chicago Press, 1979), 12-13.

${ }^{21}$ Rahman, Islam, 14-15.

22Sarjana Barat yang berpendapat demikian antara lain Gustav Weil dan Aloys Sprenger. Weil dalam bukunya, Historisch-Kritische Einleitung in der Koran, berusaha membuktikan secara ilmiah bahwa Nabi Muhammad mengidap epilepsi. Sedangkan Sprenger melalui penelitiannya hendak membuktikan bahwa Nabi selain menderita epilepsi, juga menderita histeria. Pembahasan menarik tentang hal ini dapat disimak dalam Taufik Adnan Amal, Rekonstruksi Sejarah al-Quran, cet. I, (Yogyakarta: Forum kajian Budaya dan Agama (FkBA), 2001), 73-75. 
masa kecil atau minimal pra kenabian. Nyatanya tidak, gangguan psikologi itu hanya terjadi ketika dirinya menerima wahyu.

Kondisi ketidaksadaran yang dialami Nabi Muhammad dalam kajian psikologi transpersonal merupakan potensi tertinggi yang dimiliki manusia. Potensi ini dihasilkan melalui latihan spiritual dengan teknik meditasi. Psikologi transpersonal berpendapat bahwa manusia dapat mencapai puncak kemanusiaannya apabila mengalami pengalaman spiritual yang memuncak. ${ }^{23}$

Dalam hadis diinformasikan, Nabi Muhammad pertama kali menerima wahyu ketika dirinya sedang menyepi beribadah (التحنث) (meditasi) di gua Hirā’. Al-Bukhārī, dalam karya kumpulan hadisnya yang sangat popular, Șậị alBukhārī, meriwayatkan hadis dari 'Ā'ishah:

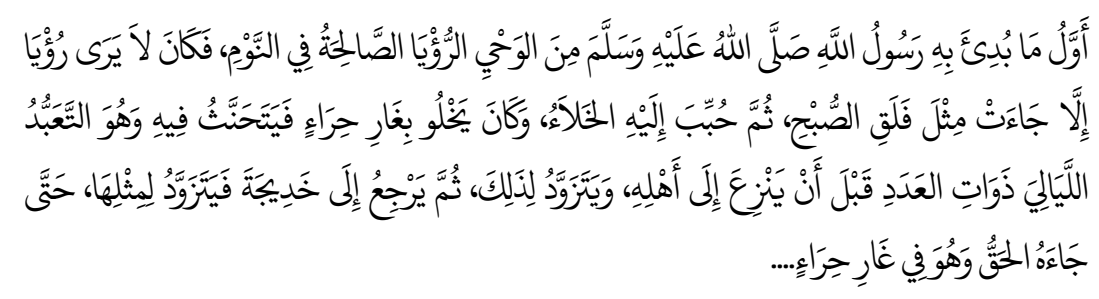

"Awal mula wahyu adalah mimpi baik, Nabi tidak mengalami mimpi kecuali sangat jelas sebagaimana cerahnya cuaca pagi hari. Lalu Nabi senang menyendiri di gua Hirā', Nabi beribadah (tahannuth) di situ hingga beberapa malam tidak pulang ke rumah. Karenanya Nabi membawa bekal secukupnya. Ketika perbekalan habis maka Nabi pulang ke rumah Khadijah untuk mengambil bekal, lalu kembali ke gua Hirā', hingga suatu ketika datanglah kepadanya al-haqq (wahyu)...."24

Menurut Jawwād 'Alī, pakar sejarah Arab pra Islam, gua Hiirā' merupakan salah satu tempat ibadah masyarakat Arab pra Islam. Masyarakat Arab saat itu memilih gua dan beberapa lokasi di dataran tinggi lainnya sebagai tempat ibadah karena memiliki keyakinan bahwa Tuhan bersemayam di atas, sehingga dengan beribadah di tempat perbukitan atau pegunungan maka lebih cepat didengar Tuhan ketimbang beribadah di dataran rendah. Beberapa tempat yang biasa dikunjungi masyarakat Arab pra Islam, termasuk Nabi Muhammad, untuk bermeditasi yaitu gua Hirā'; Abū Qubais, dan Thubair.

23Fuad Nashori, Agenda Psikologi Islam (Yogyakarta: Pustaka Pelajar, 2002), 24-25.

${ }^{24}$ al-Bukhārī, Ṣahīh al-Bukhārī, Vol. I (Beirut: Dār al-Kutub al-'Ilmiyah, 2003), 7-8. 
Bukti yang memberitahukan keaktifan Nabi Muhammad bermeditasi di tempat-tempat tersebut yaitu riwayat yang menceritakan bahwa Abū Țālib, paman Nabi Muhammad sering menyuruh orang untuk pergi ke gunung atau gua untuk mengantarkan makanan kepada Nabi yang sedang bermeditasi di tempat tersebut. ${ }^{25}$

Jadi, dengan meminjam teori psikologi transpersonal yang menekankan pada manajemen emosi dan intuisi melalui meditasi, wacana yang ditawarkan Fazlur Rahman tentang proses pewahyuan dapat dipahami dan dibenarkan secara ilmiah.

Gagasan seseorang bisa mendapatkan informasi dalam kwasi mimpi yang dihasilkan melalui pendakian spiritual juga ada dalam khazanah Islam, yaitu dalam ilmu tasawuf. Inti dari ilmu yang mempelajari kebatinan ini yaitu ketidaksadaran diri yang disebabkan oleh tingkat spiritualitasnya yang sampai pada puncak pendakian, atau biasa disebut dengan fanā'.26

Al-Ghazālī dalam Mishkāt al-Anwār memaparkan, bahwa orang-orang yang ma'rifat kepada Allah sepakat ketika sudah sampai pada puncak spiritualitasnya maka hanya menyaksikan satu wujud, yaitu wujud kebenaran tunggal (al-wāḥid al-haqq). Di antara mereka ada yang mengalaminya dengan ma'rifat ilmiyah, dan ada yang melalui rasa ( $h \bar{a} l d h a w q \bar{\imath}$ ). Keanekaragaman jagad raya menjadi lenyap, mereka tenggelam dalam ke-Esaan-Nya, akalnya tertutup, mereka seperti orang-orang yang terheran-heran dalam Zat-Nya. Mereka tidak bisa mengingat selain Allah, bahkan terhadap dirinya sendiri sekali pun. Baginya tidak ada segalanya kecuali Allah. Mereka tidak sadar diri hingga mengalahkan kendali akalnya, lalu terucaplah kata-kata dari sebagian mereka: Aku adalah Kebenaran (anā al-haqq), sebagian lainnya berucap: Maha Suci Aku, sungguh Besar Keadaan-Ku (subhānī, mā a'z̧ama syànī), ada juga di antara mereka yang berkata: Di dalam baju hanya ada Tuhan (mā fi 'l-jubbah illāllāh). ${ }^{27}$

${ }^{25}$ Baca Alī, al-Mufașsal, Vol. VI, h. 404.

${ }^{26}$ Luthfallah Khaujah, Maw Fahd, 1432 H.), h. 51-52.

${ }^{27}$ Abū Hāmid al-Ghazālī, Mishkāt al-Anwār (Kairo: ad-Dār al-Qaumiyah li al-Ṭabā'ah wa alNashr, t.th.), h. 57. Teks Arabnya:

$$
\begin{aligned}
& \text { العارفون بعد العروج إلى سماء الحقيقة اتفقوا على أنهم لم يروا في الوجود إلا الواحد الحق. لكن منهم من كان له هذه الحال }
\end{aligned}
$$

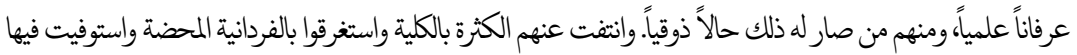


Keadaan seperti ini, menurut al-Ghazālī dinamakan dengan fanā ${ }^{\prime} u$ al-fanā' (lenyap dalam kelenyapan), yakni seseorang lenyap dari dirinya sendiri dan lenyap dari kelenyapan dirinya. Dalam keadaan seperti itu seseorang tidak merasakan kehadiran dirinya, dan tidak merasakan ketidaksadarannya. ${ }^{28}$

Dengan berdasarkan pada penafsiran QS. al-Nūr [24]: 35 dan hadis Nabi yang berisi informasi bahwa Tuhan memiliki tujuh puluh tirai berupa cahaya dan kegelapan, ${ }^{29}$ al-Ghazālī menyatakan bahwa apabila tirai-tirai yang menutup keelokan Tuhan itu tersingkap maka akal sadar seseorang akan tertutup oleh kendali kekuatan Sang Maha Agung. Dalam keadaan demikian seseorang hanya akan merasakan kehadiran Sang Maha Tunggal. Hal ini dapat dialami oleh orang-orang istimewa (khawāṣ al-khawāss) yang mendayagunakan akal pikirnya dalam mengelola batin. ${ }^{30}$

Dari sini dapat dipahami bahwa ketika seseorang sudah mencapai derajat al-ārif billāh, maka dirinya akan mengalami ketidaksadaran. Dalam keadaan tidak sadar yang oleh ahli psikologi disebut dengan kwasi mimpi, seseorang akan menerima suara-suara dari alam bawah sadarnya. Kondisi seperti ini sangat berat dirasakan, fisik dan psikisnya merasa tertekan, atau dalam istilah alQur'an شَكَيٌْ الْقُوُى (sangat kuat).31 Oleh karena itu dalam beberapa hadis yang menginformasikan tentang pewahyuan diceritakan; ketika proses penerimaan wahyu sudah selesai, Nabi merasa ketakutan yang sangat luar biasa dan

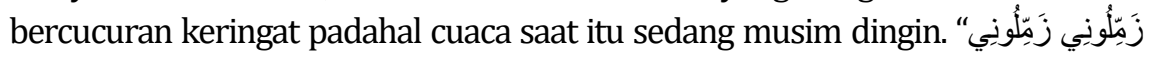

$$
\begin{aligned}
& \text { عقولم فصاروا كلمبهوتين فيه ولم يبق فيهم متسع لا لذكر غير الله ولا لذكر أنفسهم أيضاً. فلم يكن عندهم إلا الله، }
\end{aligned}
$$

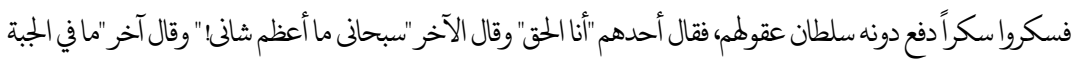

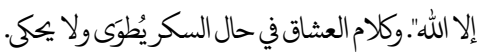

28al-Ghazālī, Mishkāt, 57-58.

${ }^{29} \mathrm{Teks}$ hadis itu berbunyi:

$$
\text { إنلله سبعين حجابا من نوروظلمة لو كشفها لأحرقت سبحات وجهه كل من أدركه بصره }
$$

"Sesungguhnya Allah memiliki tujuh puluh hijāb (tirai) berupa cahaya dan kegelapan. Apabila Allah menyingkapnya, maka cahaya wajah-Nya akan membakar siapa saja yang melihat-Nya." Lihatal-Ghazālī, Mishkāt, 39-40 dan 84-93.

${ }^{30}$ al-Ghazālī, Mishkāt, 92-93.

${ }^{31}$ QS. al-Najm [53]: 5. 
(selimutilah aku, selimutilah aku)," permintaan Nabi kepada istrinya, Khadijah.

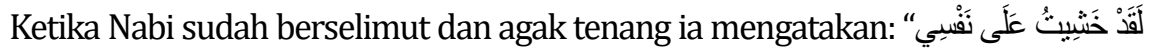
(sungguh aku merasa takut terhadap diriku sendiri). ${ }^{32}$ Dalam kondisi kwasi

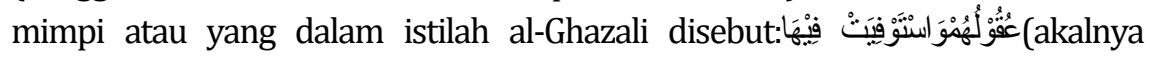
tertutup), terkadang seseorang akan mendengarkan suara-suara gemuruh yang tidak jelas, bising dan mendengung dari alam bawah sadarnya. Suara ini dalam pengalaman pewahyuan Nabi Muhammad SAW diumpamakan seperti suara

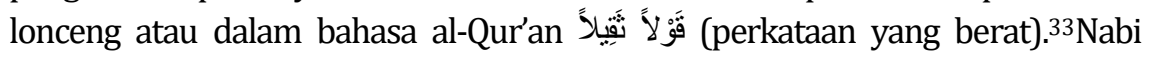
bersabda:

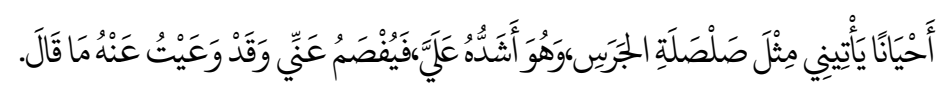

"Sesekali wahyu datang kepadaku bagai suara lonceng, dan itu sangat berat sekali bagiku, lalu setelah suara itu menghilang dariku, aku dapat memahaminya." 34

Ketika mengalami kwasi mimpi, seseorang juga terkadang di alam bawah sadarnya melihat sosok-sosok yang aneh. Dalam pengalaman kenabian Nabi Muhammad terkadang wahyu datang seakan-akan disampaikan oleh seseorang yang berbincang dengannya. Nabi bersabda:

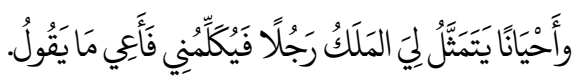

"Terkadang malaikat dengan bentuk seorang laki-laki mendatangiku. Ia mengajak berbicara kepadaku dan aku mengerti apa yang disampaikannya." 35

Sosok malaikat dalam bentuk seorang laki-laki yang ditemui Nabi dalam kondisi kwasi mimpi tidak merusak tatanan wacana internalitas wahyu dalam diri nabi, karena kehadiran sosok malaikat itu bukan wujud yang sebenarnya kasat mata, melainkan halusinasi penglihatan yang disebabkan oleh kondisi psikologis. Hal demikian juga dialami oleh para mistisisme muslim (sūfi) dalam kondisi fanā', para sufi melihat sosok-sosok aneh seperti cahaya-cahaya

\footnotetext{
32al-Bukhārī, Ṣahīḥ al-Bukhārī, Vol. I (Beirut: Dār al-Kutub al-'Ilmiyah, 2003), 7-8.

${ }^{33}$ QS. al-Muzammil [73]: 5.

34al-Bukhārī, Șahīḥ al-Bukhārī, h. 7.

35al-Bukhārī, Șahīh al-Bukhārī, 7.
} 
ketuhanan dengan berwarna warni naik menyatu dengan dirinya, naik ke atas dan yang lainnya, yang semua ini dalam keadaan sadar tidak dapat dijumpai.

Dengan menelaah gejala psikologi Nabi yang dihasilkan melalui aktivitas perenungan terdalamnya, dapat diambil sebuah konklusi bahwa wahyu yang diterima Nabi bersifat internal, bukan datang dari luar dengan bentuk visual sebagaimana yang diwacanakan oleh ortodoksi Islam.

Istilah "malaikat Jibril" yang oleh ortodoksi Islam dipahami sebagai "kurir wahyu" harus ditafsirkan sebagai "utusan spiritual", artinya bukan sosok yang berada di luar diri nabi, melainkan sebagai dorongan dari alam bawah sadar yang mengantarkan Nabi mendapatkan inspirasi ketuhanan (baca: wahyu) untuk mengubah tatanan masyarakat jahiliyah yang penuh dengan penindasan terhadap kaum dúafä:

Di dalam al-Qur'an kata Jibril telah disebut sebanyak 3 kali, yaitu dalam QS. al-Baqarah [2]: 97, 98, dan QS. al-Tahrīm [66]: 4. Penyebutan kata Jibril dalam 3 ayat itu yang memiliki keterkaitan dengan pembahasan wahyu hanya ada dalam satu ayat, yaitu dalam QS. al-Baqarah [2]: 97:

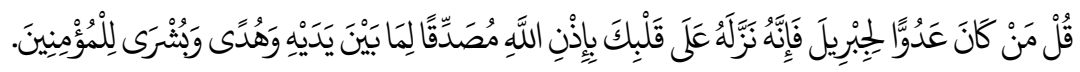

"Barang siapa yang menjadi musuh Jibril, maka Jibril itu telah menurunkannya (al-Qur'an) ke dalam hatimu (Nabi Muhammad) dengan seizin Allah, membenarkan apa (kitab-kitab) yang sebelumnya dan menjadi petunjuk serta berita gembira bagi orang-orang yang beriman."

Ketiga ayat ini semuanya disampaikan Nabi Muhammad setelah hijrah di Madinah, atau dalam istilah 'ulūm al-Qur'ān disebut dengan ayāt madānī. Dengan alasan ini para sarjana Barat mengklaim bahwa Nabi menggunakan kata "Jibril" terpengaruh oleh agama Yahudi dan Kristen yang dipeluk mayoritas penduduk Madinah. ${ }^{36}$

Persoalan berikutnya yang tak kalah urgennya dari hal ihwal internalitas wahyu, yaitu tentang "bentuk wahyu", yakni apakah wahyu yang berupa "inspirasi" itu diterima Nabi dalam bentuk verbal atau non verbal.

Perihal bentuk wahyu berkaitan erat dengan konsep internalitas proses penerimaannya. Ortodoksi Islam yang memahami bahwa wahyu diterima Nabi

36Amal, Rekonstruksi, 63-65. 
Muhammad dengan metode eksternal, yakni melalui "agen" yang bernama Jibril, dalam pembahasan ini berbeda pendapat. Al-Ālūsī dalam karyanya, Tafsìr Rūḥ al-Ma'ānī, mengklasifikasikannya menjadi tiga pendapat: ${ }^{37}$

1. Malaikat Jibril menerima wahyu dari Tuhan berupada ide (makna). Jibril mengolahnya dalam bentuk bahasa Arab, lalu disampaikan kepada Nabi Muhammad. Pendapat ini mengandaikan bahwa komunikasi antara Tuhan dengan malaikat Jibril dalam mentransfer wahyu tidak menggunakan perkataan (nonverbal), sedangkan komunikasi Jibril dengan Nabi Muhammad menggunakan perkataan (verbal) dalam bentuk bahasa Arab. Jadi yang menarasikan wahyu hingga membentuk perkataan berbahasa Arab adalah malaikat Jibril. Pengaruh kebudayaan Arab pra Islam dalam pendapat ini sangat kental; posisi malaikat Jibril sebagaimana jin dalam perdukunan dan syair, sedangkan Nabi Muhammad sejajar dengan dukun atau penyair. Tuhan bagi masyarakat Arab pra Islam diyakini bersemayam di atas, sehingga dalam pembahasan wahyu pun Tuhan diyakini bersemayam di tempat yang tidak bisa dijangkau oleh Nabi kecuali melalui "agen" berupa malaikat Jibril.

2. Malaikat Jibril menerima wahyu dari Tuhan berupa ide, dan disampaikan kepada Nabi Muhammad juga berupa ide. Lalu Nabi Muhammad mengolah redaksinya dalam bentuk bahasa Arab. Pendapat ini terkesan lebih progresif dan dapat menjelaskan mengapa wahyu yang disampaikan Nabi Muhammad kepada umatnya berupa perkataan berbahasa Arab. Pendapat ini dari sisi pemahaman wahyu sebagai pemberian "inspirasi nonverbal" serupa dengan gagasan Fazlur Rahman. Hanya saja wahyu nonverbal menurut Rahman merupakan bagian dari konsekuensi internalitas wahyu. Kendati demikian, Rahman tidak mengingkari keberadaan wahyu yang bisa saja berbentukverbal. 38

3. Malaikat Jibril menerima wahyu dari Tuhan dalam bentuk lafal yang menyerupai kode atau rumus, karenanya Jibril tidak dapat memahami maknanya. Lalu Jibril menyampaikannya kepada Nabi Muhammad. Nabi dapat memahaminya karena telah diberi pemahaman tentang wahyu tersebut.

${ }^{37}$ Syihābuddīn Maḥmūd al-Ālūsī, Tafsīr Rūḥ al-Ma'ānī, Vol. XIX, (Beirut: Dār Ihyā̄ at-Turāts al'Arabī, t.th.), 121. Lihat juga Zaid, Mafhūm al-Naș, 45-50.

38Rahman, Islam, 31-33. 
Pendapat ketiga ini hampir serupa dengan pendapat kedua, yaitu wahyu diterima Nabi berbentuk nonverbal.

Ketiga pendapat di atas sama-sama berangkat dari pemahaman eksternalitas wahyu, sehingga melibatkan malaikat Jibril sebagai pihak ketiga yang memiliki peranan penting dalam prosesi wahyu. Jika malaikat Jibril dalam pendapat pertama dan kedua diposisikan sebagai sosok yang dapat memahami kandungan wahyu, bahkan menurut pendapat pertama, malaikat Jibril telah mengambil peran sebagai "juru bicara" wahyu dari yang berupa ide menjadi kosa kata berbahasa, maka pendapat ketiga memposisikan Jibril hanya sebagai mediator yang menghubungkan antara Tuhan yang transenden dengan Nabi Muhammad yang imanen.

Dalam Al-Qur'an ditegaskan bahwa wahyu lahir di dalam hati dan pikiran Nabi Muhammad (QS. al-Shu'ārā [26]: 193, QS. al-Shūrā [42]: 24, dan QS. alBaqarah [2]: 97). Fazlur Rahman berpendapat bahwa al-Qur'an yang didapatkan Nabi melalui wahyu, secara keseluruhan adalah firman Tuhan (kalāmullāh) sekaligus sabda Nabi Muhammad (kalām Muhammad). ${ }^{39}$

Serupa dengan Fazlur Rahman, Muhammad Iqbal menyatakan bahwa alQur'an yang berasal dari wahyu merupakan karya Nabi Muhammad, yakni ide dan kata-katanya lahir dari dalam hati Nabi secara bersamaan. Namun wahyu juga dapat dikatakan sebagai kalām Tuhan karena lahir dari alam bawah sadar Nabi di luar kehendaknya sendiri. Sumber dari luar kesadaran ini menurut Iqbal adalah Tuhan.40

Gagasan kedua sarjana progresif ini hendak menegaskan bahwa wahyu diterima Nabi dalam bentuk nonverbal. Wahyu nonverbal lebih mudah dipahami dengan menggunakan pendekatan psikologi transpersonal Nabi ketika menerima wahyu. Dalam konsepsi psikologi analitis yang dikembangkan oleh Carl Gustav Jung, psikologi Nabi berada dalam ketidaksadaran kolektif, yakni Nabi mengalami ketidaksadaran diri yang dikendalikan oleh sistem dari luar yang bekerja sepenuhnya membimbing Nabi dalam ketidaksadarannya. ${ }^{41}$ Dengan demikian wahyu datang kepada Nabi dari bawah sadarnya. Karena

${ }^{39}$ Rahman, Islam, 32-33.

${ }^{40}$ Amal, Rekonstruksi, 68.

41Sarlito Wirawan Sarwono, Berkenalan dengan Aliran-aliran dan Tokoh-tokoh Psikologi, (Jakarta: Penerbit Bulan Bintang, 1978), 187-188. Lihat juga Amal, Rekonstruksi, 69-70. 
bawah sadar berada di luar diri nabi, dalam pengertian di luar kesadarannya, maka sumber wahyu dapat dinisbatkan kepada kekuatan di luar nabi, yaitu Tuhan.

Melalui pendekatan demikian dapat disimpulkan bahwa al-Qur'an dan hadis adalah "kalam Tuhan" yang diperoleh Nabi Muhammad melalui inspirasi (wahyu) dari alam bawah sadarnya. Wahyu di sini bersifat nonverbal, lalu Nabi mengverbalisasikannya ke dalam bahasa Arab sebagaimana yang hingga kini diyakini, dibaca, diucapkan, dan didengarkan oleh umat Islam di penjuru dunia.

Perenungan terdalam atau meditasi yang Nabi lakukan merupakan bentuk keprihatinannya terhadap "kekusutan realitas" saat itu. Penindasan kaum borjuis Quraisy terhadap kaum proletar, diskriminasi perempuan, perbudakan, dan praktik-praktik amoral lainnya adalah problematika hidup yang tumbuh dan subur di tengah-tengah masyarakat di mana Nabi Muhammad lahir dan besar.

Lalu dengan gejala psikologis yang dihasilkan dari perenungan, Nabi mendapatkan sederet inspirasi ilahi (wahyu) untuk memecahkan problematikaproblematika masyarakat Arab pada khususnya, dan masyarakat dunia pada umumnya. Inspirasi itu lahir dari alam bawah sadar yang bersifat nonverbal, lalu Nabi mengverbalisasikannya sesuai dengan gagasan cerdasnya dalam melakukan perubahan terhadap masyarakat. Untuk itu al-Qur'an dan hadis janganlah dipahami secara harfiah tetapi harus dipahami dengan memperhatikan konteks historis masyarakat Nabi, supaya dapat memberikan inspirasi ilahi terbaru yang melahirkan gerakan perubahan bagi umat Islam kontemporer.

\section{Hadis Qudsi Hadis Nabi dan Sunah Nabi}

Para sarjana konservatif mendefinisikan hadis qudsi dengan:

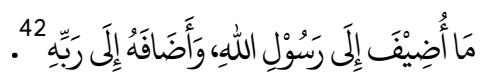

"Hadis yang disandarkan kepada Nabi Muhammad dan Nabi menyandarkannya kepada Allah."

${ }^{42} \mathrm{Abī}$ Mu'ādz Thāriq bin 'Iwadlullah, Al-Madkhal ilā 'Ilmi al-Hadīth (Riyāḍ: Dār Ibnu 'Affān, 
Dengan definisi di atas para sarjana hendak menegaskan bahwa hadis qudsi adalah "kalam Tuhan" yang disampaikan Nabi Muhammad dengan menggunakan lafaz sandaran dari satu rāwi ke rāwi berikutnya hingga sampai pada Nabi Muhammad, lalu Nabi menyandarkannya kepada Allah. Menurut Abū Shuhbah dalam bukunya, Al-Wasit fi 'Ulüm wa Muștalah al-Hadith, metode periwayatan hadis qudsi ada dua macam: Pertama, rāwi menyampaikannya dengan disandarkan kepada Nabi Muhammad seperti:

$$
\text { ......قال رسولُ اللهِِصلى الله عليه وسلم فيما يَرْوِيْهِ عن رَبِّهِ قال.... }
$$

“... Rasulullah bersabda tentang apa yang diriwayatkannya dari Allah, bahwa Allah berfirman ...."

Metode ini dipakai oleh sarjana masa lampau (țarīqah al-salaf).

Kedua, rāwi langsung menyandarkannya kepada Allah, namun dengan menyebutkan penyampainya adalah Nabi Muhammad seperti:

$$
\text { قال الله تعالى فيمايَرْوِيْهِ عنه رسولُهُصلى الله عليهوسلم: ..44 }
$$

"Allah berfirman seperti yang diriwayatkan utusan-Nya ...."

Cara ini dikembangkan oleh generasi belakangan (tarïqah al-khalaf).

Jika hadis Qudsi didefinisikan para ulama hadis di atas merupakan perkataan Nabi yang disandarkan kepada Tuhan, yakni lafal yang diucapkan secara verbal dengan melalui alat bantu lisan nabi, namun ide (makna) yang terkandung di dalamnya merupakan ide yang bersumber dari Tuhan. Maka bagaimana dengan "ḥadith nabawì" dan "sunnah nabawiyyah", maka jika keduanya merupakan perkataan dan perbuatan dari Nabi Muhammad, tetapi mengapa keduanya dibedakan dengan hadis Qudsi. Karena itu, dengan teori pewahyuan dan dengan pendekatan tranpersonal psikologi di atas dapat memberikan pemahaman bahwa hadis nabawi, dan hadis qudsi, keduanya berasal dari inspirasi ilahi (wahyu) yang tidak berbentuk perkataan dan bukan pula berbentuk bahasa. Lalu, Nabi menciptakannya dengan sebuah untaian bahasa manusia. Dengan pendekatan tranpersonal psikologi, maka al-qur'an pun nyaris tidak ada perbedaan antara hadis nabawi dan hadis qudsi.

43Muhammad bin Abū Shuhbah, Al-Wasịt fi Ulūm wa Muștalah al-Hadīth (Beirut: Dār al-Fikr al-'Arabì, t.th.), h. 221-222. 
Adapun pengertian sunnah menurut mayoritas sarjana yaitu menyamakan istilah sunnah dengan istilah hadis, tetapi Fazlur Rahman membedakan pada kedua istilah tersebut. Menurut Fazlur Rahman, sunnah adalah transmisi (riwāyah) non verbal, sedangkan hadis adalah transmisi verbal. Tetapi seiring dengan berjalannya waktu,maka sunnah berubah menjadi hadis dikarenakan para sarjana melakukan verbalisasi terhadap sunnah dan menyusun matarantai hingga sampai pada Nabi Muhammad. ${ }^{44}$

Menurut Ibn al-Șalāḥ (w. 643 H.), pakar fiqh mazhab Syafi'i, ketika ditanya tentang perbedaan antara sunnah dan hadis, ia menjawab:

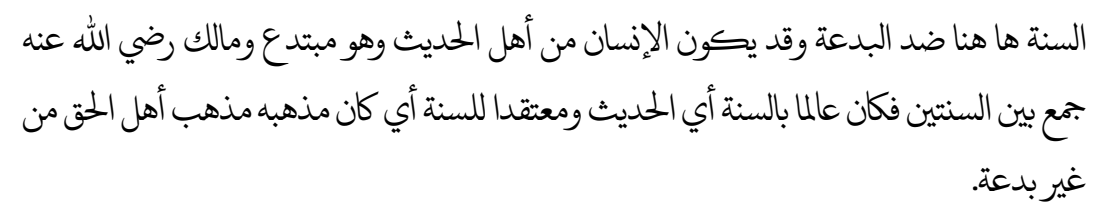

Maksudnya: "al-Sunnah menurut Ibn al-Ṣalāh adalah kebalikan daripada bid'ah. Seseorang terkadang sangat 'alim dalam bidang hadis tetapi terkadang melakukanperbuauat bid'ah. Sedangkan Imam Malik, ia mengerti tentang hadis dan beri'tikad mengikuti mazhab yang benar, bukan mazhab ahli bid'ah." 45

Dengan demikian Ibn al-Ṣalāh sependapat dengan pandangan bahwa sunnah berbeda dengan hadis. Yaitu sunnah merupakan praktik keislaman Nabi dan sahabatnya, sehingga perbuatan yang tidak pernah diperaktekkan Nabi adalah bid'ah. Sedangkan hadis adalah ungkapan dan perkataan Nabi Muhammad serta pengakuan Nabi Muhammad terhadap ungkapan dan tindakan sahabat yang berkaitan dengan persoalan hukum (taqrīr).

Dari semua pandangan para ulama di atas, hampir semua mereka mendefinisikan sunnah nabi adalah perilaku Nabi Muhammad sebagai subjek figur sentral yang selalu diikuti oleh umatnya baik dalam ucapan maupun dalam segala kegiatannya.

Itu semua merupakan bagian kecil keragaman definisi dan fungsi hadis yang diwacanakan para sarjana. Perbincangan hadis qudsi nyaris tidak banyak

${ }^{44}$ Rahman, Islam, h. 69.

45Ibn al-Ṣalāḥ, Fatāwā Ibn al-Ṣalāḥ (Beirut: Maktabah al-'Ulūm wa 'l-Ḥikam, 1407 H.), h. 213. 
diperbincangkan mereka, mungkin karena ada kesan bahwa hadis qudsi hanya berisi persoalan-persoalan metafisik dan keutamaan-keutamaan beramal (fậāill al-a'māl).

Misalnya hadis tentang keutamaan seseorang yang berpuasa, Nabi bersabda:

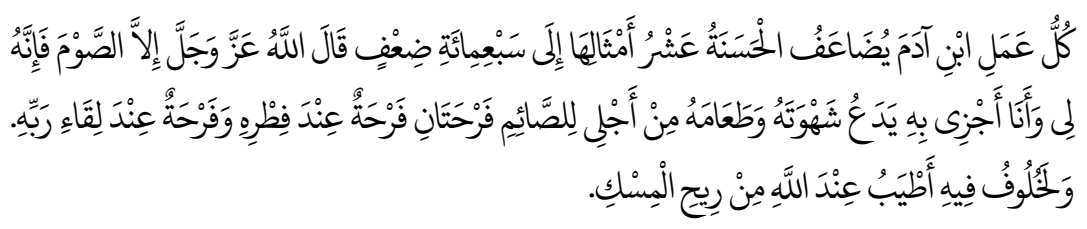

"Setiap amalan kebaikan yang dilakukan oleh manusia akan dilipatgandakan dengan sepuluh kebaikan yang semisal hingga tujuh ratus kali lipat. Allah Ta'ala berfirman, "Kecuali amalan puasa. Amalan puasa tersebut adalah untuk-Ku. Aku sendiri yang akan membalasnya. Disebabkan dia telah meninggalkan syahwat dan makanan karena-Ku. Bagi orang yang berpuasa akan mendapatkan dua kebahagiaan yaitu kebahagiaan ketika dia berbuka dan kebahagiaan ketika berjumpa dengan Rabbnya. Sungguh bau mulut orang yang berpuasa lebih harum di sisi Allah daripada bau minyak kasturi."

Kedudukan hadis qudsi di mata para sarjana muslim sama dengan hadis nabawi, yakni tergantung kepada kuat dan lemahnya rāwi (sanad). Hadis qudsi ada yang memiliki kualitas sanad kuat (șahịh), baik (hasan), dan lemah (ḍaî́f). Demikian juga dengan semua pembagian hadis yang berdasarkan pada penyampainya ( $\left.a l-q \bar{a}{ }^{\prime} i l\right)$ seperti al-marfü', al-mawqüf, al-maqțü', dan yang lainnya berlaku pula dalam hadis qudsi.

Salah satu kemusykilan dalam studi hadis qudsi sebagaimana yang terlihat dari definisi di atas adalah kedudukannya yang diklaim sebagai "kalam Tuhan", yakni maknanya dari Tuhan, dan lafadhnya dari Nabi Muhammad. Penyandaran kepada Tuhan adalah sebagai pembeda dari hadis nabawi, yaitu hadis yang lafadh dan maknanya bersumber dari Nabi. Penyandaran makna kepada Tuhan dan lafal kepada Nabi juga sebagai pembeda dari al-Qur'an yang didefinisikan sebagai kalam Tuhan baik makna maupun lafadhnya.

Apabila ditelusuri historisitasnya, maka akan ditemukan bahwa konsep hadis qudsi seperti ini merupakan formulasi sarjana abad kedua dan ketiga hijriyah yang bertalian erat dengan konsepsi wahyu yang mereka rumuskan. Sehingga apabila konsep wahyu klasik mengharuskan rekonstruksi lantaran ada kecacatan motodologis, maka konsep hadis qudsi pun meniscayakan redefinisi. 
Definisi yang bisa diajukan di sini adalah hadis qudsi baik makna maupun

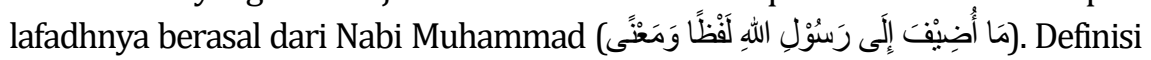
ini berdasarkan pada konsep internalitas wahyu sebagaimana dipaparkan di atas. Dalam QS. al-Najm [53]: 3-4 ditegaskan bahwa Nabi Muhammad tidak berbicara kecuali berdasarkan pada wahyu yang diterimanya:

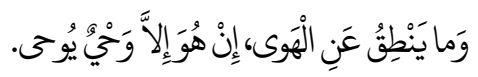

"Dan tiadalah yang diucapkannya itu menurut kemauan hawa nafsunya. Ucapannya itu tiada lain hanyalah wahyu yang diwahyukan."

Berdasarkan ayat ini, semua yang disampaikan Nabi Muhammad baik berupa al-Qur'an maupun hadis adalah wahyu yang diterimanya dari alam bawah sadar. Pengalaman kenabian yang menjadikan Nabi Muhammad mengalami ketidaksadaran (kwasi mimpi) terjadi berulang kali, baik di waktu siang maupun malam. Sejak pertama kali Nabi menerima wahyu, Nabi sangat sering berpuasa di siang hari, dan bertahajjud pada malam harinya. Menurut J. Mueller,46 pengolahan jiwa dengan cara demikian dapat meningkatkan kemampuan rukyah (visionsvermoegen) atau dalam istilah tasawuf disebut dengan fanā', dan "menggapai potensi kemanusiaan tertinggi" dalam psikologi transpersonal.

Gangguan psikologi Nabi Muhammad saat menerima wahyu, menjadikan diri Nabi terlempar ke dalam "ruang" ketidaksadaran. Dalam keadaan demikian datanglah wahyu nonverbal dari alam bawah sadarnya yang kemudian Nabi mengolahnya dalam bentuk perkataan dan tindakan. Perkataan dan tindakan ini kemudian ada yang menjadi al-Quran, dan ada yang menjadi hadis.

Jadi, secara subtansi tidak ada perbedaan antara al-Qur'an, hadis nabawi dan hadis qudsi karena ketiganya menggunakan pendekatan sebuah teori psikologi transpersonal, semuanya berasal dari wahyu yang bersifat internal (lahir dari lubuk hati terdalam nabi) dan nonverbal (tidak berbentuk perkataan), maka hadis pun demikian. Tiga kategori perkataan Nabi Muhammad yang berupa al-Qur'an, hadis nabawi, dan hadis qudsi, semuanya berasal dari inspirasi ilahi (wahyu) yang tidak berbentuk perkataan dan sepi dari bahasa. Lalu, Nabi menciptakannya dalam untaian bahasa manusia (kosa-kata), dan menampak-

\footnotetext{
${ }^{46}$ Amal, Rekonstruksi, 70-71.
} 
kannya dalam perilaku kesehariannya sesuai dengan misi dan visi inspirasi itu, yakni membebaskan orang-orang yang tertindas.

\section{E. Kesimpulan}

Melalui kajian psikologi transpersonal, Nabi Muhammad ketika menerima wahyu dari Allah, dapat disimpulkan bahwa wahyu sebagaimana makna asalnya adalah "inspirasi" yang bersifat "internal" (lahir dari dalam diri Nabi melalui alam bawah sadarnya) dan "nonverbal" (tidak berbentuk perkataan). Dari inspirasi itu, Nabi menyampaikannya kepada para sahabatnya dengan menggunakan media kosa-kata berbahasa supaya dapat dipahami dan dipraktikkan umat manusia sebagai ajaran Islam.

Di sinilah wahyu yang mulanya berupa inspirasi dan bersifat abstrak, oleh Nabi Muhammad dikonkretkan dalam bentuk "sabda". Lalu seiring dengan berjalannya waktu, tepatnya sejak ilmu-ilmu keislaman mulai dikodifikasi, para sarjana muslim memilah dan memilih sabda-sabda Nabi itu ke dalam tiga kategori, yaitu: "al-Quran", "hadis nabawi", dan "hadis qudsi".

Jadi hadis qudsi yang dikonsepsikan oleh sarjana klasik yang mengklaim sebagai "kalam Tuhan", yakni maknanya dari Tuhan, dan lafaznya dari Nabi Muhammad merupakan pendefinisian yang bias secara ilmiah. Karena dengan penggunaan bahasa lokalitas Nabi. yakni dengan bahasa Arab pada "tiga teks suci" di atas dapat dipahami secara rasional. Bahasa teks suci adalah bahasa Nabi Muhammad itu sendiri, bukan bahasa Tuhan, karena wahyu tidak menggunakan perkataan yang berbahasa. Wahyu adalah inspirasi yang lahir dari dalam diri nabi, lalu Nabi menyampaikannya dalam bentuk kata-kata dan tindakan sebagai perwujudan dari pesan kenabian yang membawa rahmat bagi semesta alam (rahmatan li al-'älamīn).]

\section{DAFTAR PUSTAKA}

Abdurrahman, Abu Sahl Muhammad bin. al-Mawsū'ah. Mesir: al-Nabla, t.th.

Alī, Jawwād. al-Mufașșal fi Tārīkh al-'Arab qabla al-Islām. Universitas Baghdad, t.th.

al-Ālūsī, Syihābuddīn Maḥmūd. Tafsīr Rūḥ al-Ma'ānī. Beirut: Dār Ihyā’ al-Turāts al'Arabì, t.th. 
al-Anșārī, Ibnu Mandhūr, Lisān al-'Arab. Beirut: Dār Shādir, 1414 H.

al-Bāqī, Muhammad Fūād 'Abd. al-Mu'jam al-Mufahras li Alfāz al-Qur'ān al-Karīm. Kairo: Dār al-Hadīth, $1364 \mathrm{H}$.

al-Bukhārī, Șahịḥ al-Bukhārī. Beirut: Dār al-Kutub al-'Ilmiyah, 2003.

al-Ḍabbī, al-Mufaḍal bin Muḥammad. al-Mufaḍdạaliyāt. Kairo: Dār al-Ma’ārif, t.th.

al-Ghazālī, Abū Ḥāmid. Mishkāt al-Anwārr. Kairo: ad-Dār al-Qaumiyah li al-Ṭabā’ah wa al-Nashr, t.th.

Ibn 'Iwadlullah, Abī Mu'ādz Thāriq. al-Madkhal ilā 'Ilmi al-Hadìth. Riyāḍ: Dār Ibnu 'Affān, 2003.

Ibnu Kathīr, Abū al-Fidā, Tafsīr al-Qur'ān al-'Azīim. Beirut: Dār al-Kutub al-'Ilmiyah, $1419 \mathrm{H}$.

Ibn al-Ṣalāḥ, Fatāwā Ibn al-Ṣalāh. Beirut: Maktabah al-'Ulūm wa 'l-Hikam, 1407 H.

Khaujah, Luthfallah. Mawdū'at-Tașawwuf. Makkah al-Mukarramah: Maktabah alMalik Fahd, $1432 \mathrm{H}$.

Nashori, Fuad, Agenda Psikologi Islam. Yogyakarta: Pustaka Pelajar, 2002.

Ouzon, Zakaria. Jināyah al-Bukhārī; Inqādh al-Dīn min Imām al-Muhaddithīn. Beirut: Riad El-Rayyes Books, 2004.

al-Qurțubī, Abū 'Abdillah al-Jāmi' li Aḥkām al-Qur'ān. Kairo: Dār al-Kutub alMishriyah, 1964.

Rahman, Fazlur. Islam. Chicago-London: University of Chicago Press, 1979.

al-Rāzī, Fakhruddīn. Tafsìr Mafātịh al-Ghayb. Beirut: Dār al-Kutub al-'Ilmiyah, 2000.

al-Ṣaaliḥ, Subḥi. 'Ulūm al-Hadìth wa Muștalaḥuhu. Beirut: Dār al-'Ilm li'l-Malayin, 1978.

Sarwono, Sarlito Wirawan. Berkenalan dengan Aliran-aliran dan Tokoh-tokoh Psikologi. Jakarta: Penerbit Bulan Bintang, 1978.

Shuhbah, Muhammad bin Abū. al-Wasìt fi 'Ulūm wa Muștalah al-Hadïth. Beirut: Dār al-Fikr al-'Arabī, t.th. 
al-Ṭabarī, Muhammad Ibnu Jarīr. Jāmi' al-Bayān fi Ta wìl al-Qur'ān. ttp., Mu'assasah al-Risālah, 2000.

Walsh, R. \& Vaughan, F. "On transpersonal definitions".Journal of Transpersonal Psychology, 25 No. 2 (1993): 125-182.

Zaid, Nașr Ḥāmid Abū. Mafhūm al-Naș; Dirāsah fi 'Ulūm al-Qur'ān. Mesir: al-Hai'ah al-Mishriyah al-'Āmmah li al-Kitāb, 1990.

al-Zamakhsyarī, Abū al-Qāsim. al-Kashshāf 'an Haqāiiq Ghawāmị̣ al-Tanzīl. Beirut: Dār al-Kitāb al-'Arabī, 1407 H.

al-Zarqānī, Abdul ‘Azịm, Manāhil al-Irfān. Kairo: Dār al-Hadīth, 2001. 
